\title{
Development and Experimental Research of Materials for Forming Stable Bottom and Side Ledges
}

\author{
Gennadiy V. Arkhipov*a, Peter V. Poliakov, \\ Evgeniy R. Shaydulin ${ }^{a}$ and Yuriy O. Avdeeva \\ $a$ «RUSAL ETC» LTD \\ 37 Pogranichnikov, Krasnoyarsk, 660111, Russia \\ ${ }^{b}$ Siberian Federal University \\ 79 Svobodny, Krasnoyarsk, 660041, Russia
}

Received 07.03.2016, received in revised form 22.05.2016, accepted 14.07.2016

The main purpose of this paper is to find a solution for saving energy in the cell room. Another purpose of the paper is to find materials suitable for stable side and bottom ledge formation, research the properties of such materials, and study their behavior in cryolite-alumina melts, including selection of the most suitable material. Moreover, the paper is concerned with energy consumption reduction by forming stable side and bottom ledges. Furthermore, as mentioned earlier, several materials have been selected to form stable side and bottom ledges during the post-start-up period. The properties of the selected materials have been analyzed.

Keywords: Electrolysis, electrolytic cell, start-up of electrolytic cell, forming stable bottom and side ledges.

Citation: Arkhipov G.V., Poliakov P.V., Shaydulin E.R., Avdeev Y.O. Development and experimental research of materials for forming stable bottom and side ledges, J. Sib. Fed. Univ. Eng. technol., 2016, 9(5), 617-631. DOI: 10.17516/1999-494X-20169-5-617-631.

(c) Siberian Federal University. All rights reserved

* Corresponding author E-mail address: Gennadiy.Arkhipov@rusal.com 


\title{
Разработка и экспериментальные исследования
}

\section{материала для формирования устойчивой}

\section{настыли и гарнисажа}

\author{
Г.В. Архипов ${ }^{a}$, П.В. Поляков ${ }^{\sigma}$, \\ Е.Р. Шайдулин ${ }^{\mathrm{a}}$, О.О. Авдеев ${ }^{\mathrm{a}}$ \\ ООО «РУСАЛ ИТЦ»
}

Россия, 660111, Красноярск, Пограничников, 37/1

Сибирский федеральный университет

Россия, 660041, Красноярск, пр. Свободный, 79

Целью данной работь является разработка технических решений для повышения энергоэффективности действующих алюминиевых электролизеров, включающая подбор материалов для создания искусственной настыли и экспериментальные исследования свойств выбранных материалов, их поведения в криолитоглиноземных расплавах с последующим выбором материала с оптимальными свойствами, а также снижение удельного расхода электроэнергии за счет создания искусственной настыли и гарнисажа. По результатам работы установлены два вида материалов для создания искусственной настыли: на основе $\mathrm{SiC-SiN} \mathrm{композищии,} \mathrm{на} \mathrm{основе} \mathrm{магнезита.} \mathrm{Оба} \mathrm{вида} \mathrm{материалов} \mathrm{показали} \mathrm{хорошую} \mathrm{стойкость}$ в расплаве электролита и могут быть рекомендованы для создания искусственной настыли.

Ключевые слова: электролиз, электролизер, пуск электролизера, образование устойчивой настыли и гарнисажа.

\section{Introduction}

During the post-start-up period, all the process parameters have to reach the desired values, and protective side and bottom ledges have to be formed. It is clear that the shorter the post-start-up period is, the less it takes time for the cell to start operating at the full performance level. The limiting stage of the post-start-up period is the process of bottom and side ledge formation, which makes the cell work at a higher target voltage level to preserve its energy balance.

Faster bottom and side ledge formation could shorten the post-start-up period and reduce the target voltage quicker, which, in turn, could lead to a reduction in the specific power consumption.

This paper deals with the development of solutions for optimizing currently operating cells, including selection and testing of materials for forming artificial ledges; and investigates the behavior of these materials in cryolite-alumina melts (for the purpose of choosing the most suitable material.) This paper also discusses the possibility of reducing the specific power consumption by means of forming artificial bottom and side ledges.

\section{Development of technical solutions for reducing}

\section{the anode-to-cathode distance in aluminum electrolysis cells}

Selecting new materials for ledge formation

Silicon carbide and magnesite blocks were selected as promising materials for ledge formation. In the aluminum industry, silicon carbide blocks have been used as a side lining material for the aluminum reduction cell cathode for a long time. Magnesite blocks are used as a side lining material 
Table 1. Composition and some physical features of silicon carbide blocks and magnesite blocks

\begin{tabular}{|c|c|c|}
\hline Components and features & Silicon carbide blocks & Magnesite blocks \\
\hline $\mathrm{SiC}, \%$ mass & 72.90 & \\
\hline $\mathrm{SiO}_{2}, \%$ mass & 0.99 & 1.86 \\
\hline $\mathrm{Al}_{2} \mathrm{O}_{3}, \%$ mass & 1.20 & 8.28 \\
\hline $\mathrm{Si}_{3} \mathrm{~N}_{4}, \%$ mass & 24.50 & \\
\hline $\mathrm{N}_{2}, \%$ mass & 9.80 & 87.00 \\
\hline $\mathrm{MgO}, \%$ mass & & 1.20 \\
\hline $\mathrm{CaO}, \%$ mass & & $2.60-2.80$ \\
\hline Density, $\mathrm{g} / \mathrm{cm}{ }^{3}$ & $2.63-2.66$ & $17.10-19.30$ \\
\hline Porosity, $\%$ & 12.30 & \\
\hline
\end{tabular}

in the aluminum refining cell (three-layer refining.) The composition and some physical parameters of silicon carbide and magnesite blocks are listed in Table 1.

\section{Thermal conductivity of silicon carbide}

and magnesite blocks

The coefficient of thermal conductivity $(\lambda)$ of silicon carbide blocks is one of the crucial properties which define side ledge formation. Carbon blocks were superseded by silicon carbide blocks mainly because of a high thermal conductivity of the latter. According to the Siacatec 75 Quality Certificate, the coefficient of thermal conductivity of the blocks lowers as the temperature rises. Figure 1 shows $\lambda$ vs. (temp.) within the temperature range of 20 to $900^{\circ} \mathrm{C}$, which falls quite well on the straight line described by the following equation:

$$
\lambda=45.153-0.0285 \mathrm{t}, \mathrm{W} / \mathrm{m} \cdot \mathrm{K},
$$

where ' $\mathrm{t}$ ' stands for the temperature measured in ${ }^{\circ} \mathrm{C}$.

Figure 2 shows $\lambda$ vs. (temp.) within the temperature range of 300 to $1,200^{\circ} \mathrm{C}$, according to [1]. The dependency becomes non-linear at $\mathrm{t}>800^{\circ} \mathrm{C}$.

During cell operation, the coefficient of thermal conductivity of the blocks decreases. According to [2], a reduction in the coefficient of thermal conductivity may reach $38 \%$ and $77 \%$. Figure 3 shows an even more severe decrease, which was seen during the research period [3]. For instance, for a block taken out from a 270-day-old, shut-down cell, the coefficient of thermal conductivity of the material contacting the bath, at 550 to $700{ }^{\circ} \mathrm{C}$ (the temperature of the block during cell operation; the cell with the side ledge), was 3 times lower than the initial value $(28 \mathrm{~W} / \mathrm{m} \cdot \mathrm{K})$, which is equal to the coefficient of thermal conductivity of carbon blocks. It is clear that a decrease in thermal conductivity leads to side ledge melting.

The coefficient of thermal conductivity decreased significantly only at the areas of contact with the bath, whereas in the gas-phase area the coefficient of thermal conductivity barely changed. Such a significant decrease in the bath area may be caused by the formation of sodium silicate, which is characterized by a lower thermal conductivity. 


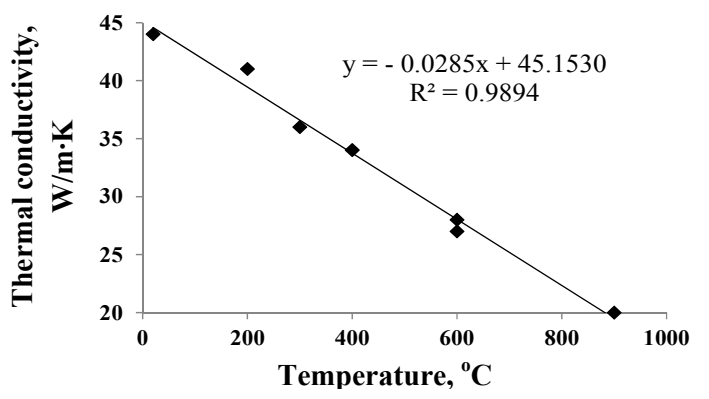

Fig. 1. Thermal conductivity vs. temperature for silicon carbide blocks

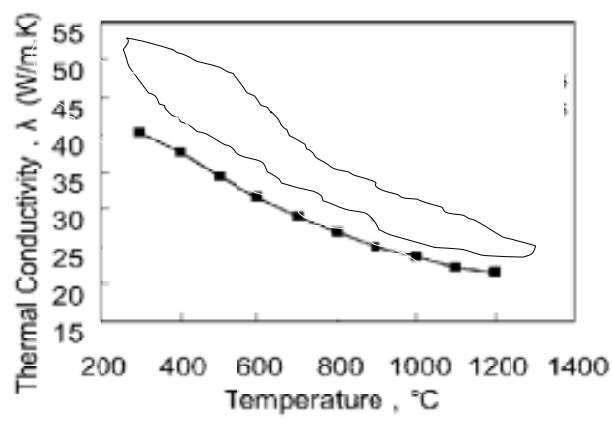

Fig. 2. Thermal conductivity vs. temperature for silicon carbide blocks, according to [3]

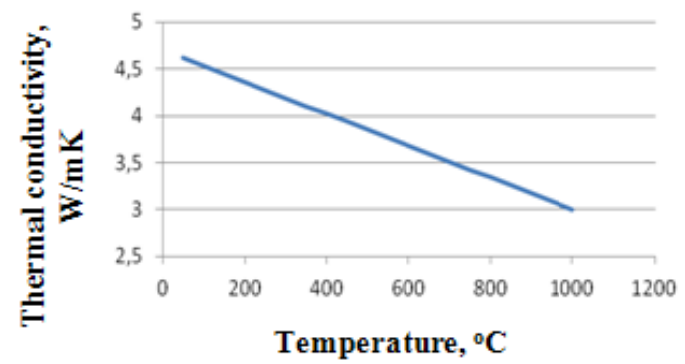

Fig. 3. Thermal conductivity vs. temperature for magnesite blocks, according to [4]

Figure 3 shows thermal conductivity vs. temperature for magnesite blocks, which is described by the following equation (according to [4]):

$$
\lambda=4.7-0.0017 \mathrm{t}, \mathrm{W} / \mathrm{m} \cdot \mathrm{K},
$$

where ' $\mathrm{t}$ ' stands for temperature measured in ${ }^{\circ} \mathrm{C}$.

Figure 4 shows thermal conductivity vs. temperature for magnesite blocks, which is described by the following equation (according to [5]):

$$
\lambda=5+0.0015 \mathrm{t}, \mathrm{W} / \mathrm{m} \cdot \mathrm{K},
$$

where ' $\mathrm{t}$ ' stands for the temperature measured in ${ }^{\circ} \mathrm{C}$. 
Since the thermal conductivity measurements described in the literature differ significantly, several independent experiments were conducted during this research to define the coefficient of thermal conductivity of magnesite blocks.

\section{Specific electrical resistivity}

Figures 5 and 6 show specific electrical resistivity, $\rho$ vs. temperature for silicon carbide and magnesite blocks [5].

As shown in the above graphs, the specific electrical resistivity of both silicon carbide and magnesite blocks decreases significantly when the temperature rises. Within the temperature range of 25 to $800^{\circ} \mathrm{C}$, electrical resistivity vs. temperature is described by the following linear equation:

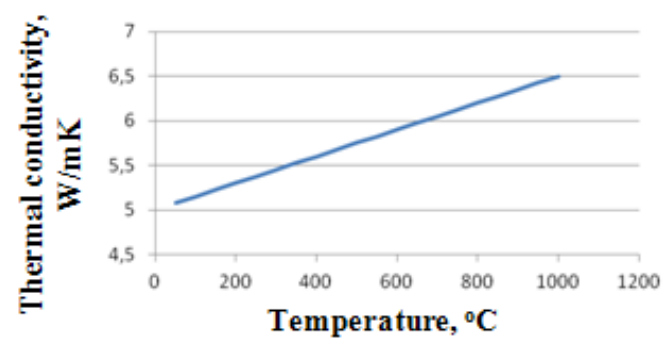

Fig. 4. Thermal conductivity vs. temperature for magnesite blocks, according to [5]

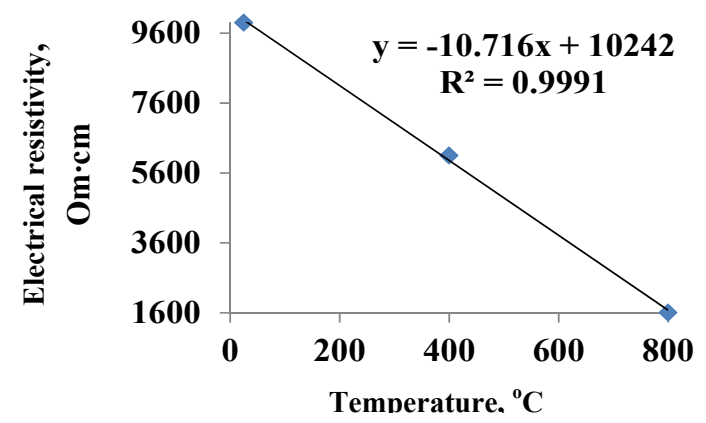

Fig. 5. Specific electrical resistivity vs. temperature for silicon carbide blocks

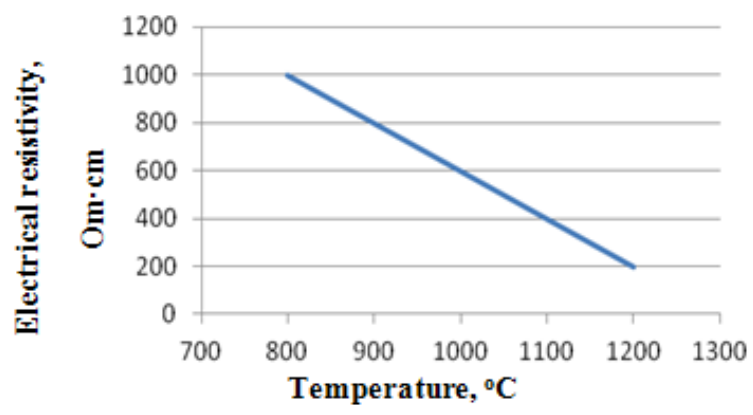

Fig. 6. Specific electrical resistivity vs. temperature for magnesite blocks [5] 


$$
\rho=10,242-10,716 \cdot \mathrm{t}, \mathrm{Ohm} \cdot \mathrm{cm},
$$

where ' $\mathrm{t}$ ' stands for the temperature measured in ${ }^{\circ} \mathrm{C}$.

\section{Experimental research of silicon carbide and magnesite blocks for ledge formation purposes}

The following materials were provided for testing:

- periclase-spinel refractory based on sintered periclase and aluminum spinel. Block type: PShGS-64 (ПШГС-64), manufactured by Magnesit, LLC, the city of Satka, Russia. Block size: $600 \times 230 \times 90 \mathrm{~mm}$;

- silicon carbide block, manufactured by the Volzhskiy Abrasive Works, block size: $350 \times 350 \times 65 \mathrm{~mm}$.

Samples $(\varnothing 35 \times 90 ; \varnothing 40 \times 50 ; \varnothing 65 \times 50 \mathrm{~mm})$ were taken from the above materials by drilling and lathing.

The following characteristics of the materials were defined:

- spinning wear in the bath and molten aluminum;

- thermal expansion within the temperature range of 20 to $950{ }^{\circ} \mathrm{C}$; and

- thermal conductivity within the temperature range of 100 to $950{ }^{\circ} \mathrm{C}$.

Spinning wear of silicon carbide and magnesite blocks

in the bath and molten aluminum

The tests were run using an erosive wear measurement system in accordance with the erosive wear testing methodology for spinning samples in the bath and molten aluminum. Figure 7 shows the sample appearance.

Silicon carbide blocks are difficult to lathe, so it was impossible to make a cylindrical sample. Silicon carbide and magnesite samples were made in the form of octagon, which was the closest to the form of a cylinder. The dimensions of the samples are listed in Table 3.

The samples were mounted (Fig. 7), put into the chamber filled with molten aluminum and the bath and, then, were spun at a certain speed. The aluminum level was $25 \mathrm{~mm}$, and the bath level was

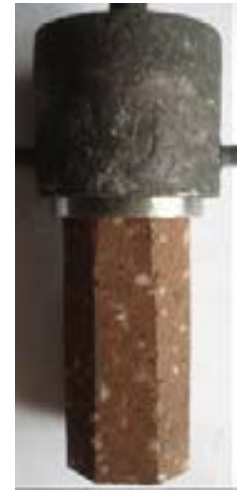

a

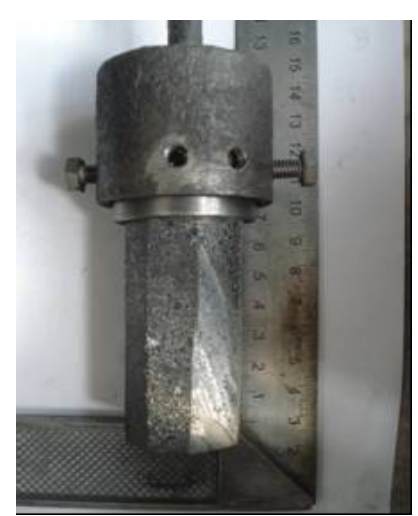

b

Fig. 7. Mounted samples, before spinning in the bath and aluminum: a - magnesite block; $b$ - silicon carbide block 
$25 \mathrm{~mm}$. Table 2 shows the experimental composition of the bath. During testing, the bath temperature was $980^{\circ} \mathrm{C}$.

Silicon carbide blocks. The test results are listed in Table 3 and shown in Fig. 8-9 demonstrates the cross-section of the sample at the aluminum/bath interface after spinning in the bath/Al system for 12 hours.

The appearance of the samples and the cross-section of Sample 2 did not change as a result of the tests (as shown in Fig. 8, 9) This means that the material did not react with the bath. The change in the sample dimensions as a function of time / height is shown in Fig. 10 and 11.

The graphs show that the maximum wear of the silicon carbide samples is observed on the edges both in the area of contact with aluminium and in the aluminum/bath interface area after 12 hours. The distance between the longitudinal edges decreased by $0.36 \mathrm{~mm}$ and $0.44 \mathrm{~mm}$, respectively.

Magnesite blocks, PShGS-64 (ПШГС-64). The appearance of the samples before and after the test is shown in Fig. 12 After 12-hour and 24-hour experiments, the samples were cross cut at a height

Table 2. Experimental bath composition

\begin{tabular}{|c|c|c|c|c|}
\hline $\begin{array}{c}\mathrm{Na}_{3} \mathrm{AlF}_{6}+\mathrm{AlF}_{3} \\
(\mathrm{CR}=2,0)\end{array}$ & $\mathrm{NaF}$, Analytical grade & $\mathrm{Al}_{2} \mathrm{O}_{3}$, Analytical grade & $\mathrm{CaF}_{2}$, Analytical grade & $\mathrm{CR}$ \\
\hline $77, \%$ by mass & $14, \%$ by mass & $4, \%$ by mass & $5, \%$ by mass & 2,65 \\
\hline
\end{tabular}

$\mathrm{CR}$ - cryolite ratio.

Table 3. Test results: measuring the spinning wear of silicon carbide blocks in the bath-aluminum system

\begin{tabular}{|c|c|c|c|c|c|c|c|}
\hline $\begin{array}{l}\text { Test } \\
\text { No. }\end{array}$ & $\begin{array}{l}\text { Testing } \\
\text { time, hours }\end{array}$ & $\begin{array}{l}\text { Sample spinning } \\
\text { speed, } \mathrm{cm} / \mathrm{s}\end{array}$ & \multicolumn{2}{|c|}{$\begin{array}{l}\text { Average sample dimensions } \\
\text { and mass }\end{array}$} & Before test & After test & Difference \\
\hline \multirow{8}{*}{1} & \multirow{8}{*}{6} & \multirow{8}{*}{16} & $\mathrm{D}_{\mathrm{pl} .}^{*}, \mathrm{~mm}$ & \multirow{2}{*}{ at the bottom } & 33.400 & 33.400 & 0.000 \\
\hline & & & $\mathrm{D}_{\text {ed. }}{ }^{* *}, \mathrm{~mm}$ & & 35.520 & 35.450 & -0.070 \\
\hline & & & $\mathrm{D}_{\mathrm{pl} .}{ }^{*}, \mathrm{~mm}$ & \multirow{2}{*}{$\begin{array}{l}\text { at the height of } \\
25 \mathrm{~mm}\end{array}$} & 33.530 & 33.450 & -0.080 \\
\hline & & & $\mathrm{D}_{\text {ed. }}{ }^{* *}, \mathrm{~mm}$ & & 35.880 & 35.760 & -0.120 \\
\hline & & & $\mathrm{D}_{\mathrm{pl} .}{ }^{*}, \mathrm{~mm}$ & \multirow{2}{*}{$\begin{array}{l}\text { at the height of } \\
50 \mathrm{~mm}\end{array}$} & 33.212 & 33.175 & -0.037 \\
\hline & & & $\mathrm{D}_{\text {ed. }}{ }^{* *}, \mathrm{~mm}$ & & 34.920 & 34.780 & -0.140 \\
\hline & & & \multicolumn{2}{|c|}{ Height, $\mathrm{mm}$} & 88.700 & 88.700 & 0.000 \\
\hline & & & \multicolumn{2}{|c|}{ Mass, grams } & 208.200 & 208.200 & 0.000 \\
\hline \multirow{8}{*}{2} & \multirow{8}{*}{12} & \multirow{8}{*}{32} & $\mathrm{D}_{\mathrm{pl} .}{ }^{*}, \mathrm{~mm}$ & \multirow{2}{*}{ at the bottom } & 32.275 & 32.250 & -0.025 \\
\hline & & & $\mathrm{D}_{\text {ed. }}{ }^{* *}, \mathrm{~mm}$ & & 34.300 & 33.940 & -0.360 \\
\hline & & & $\mathrm{D}_{\mathrm{pl} .}{ }^{*}, \mathrm{~mm}$ & \multirow{2}{*}{$\begin{array}{l}\text { at the height of } \\
25 \mathrm{~mm}\end{array}$} & 33.025 & 33.175 & 0.150 \\
\hline & & & $\mathrm{D}_{\text {ed. }}{ }^{* *}, \mathrm{~mm}$ & & 34.580 & 34.140 & -0.440 \\
\hline & & & $\mathrm{D}_{\mathrm{pl} .}{ }^{*}, \mathrm{~mm}$ & \multirow{2}{*}{$\begin{array}{l}\text { at the height of } \\
50 \mathrm{~mm}\end{array}$} & 32.775 & 32.550 & -0.225 \\
\hline & & & $\mathrm{D}_{\text {ed. }}{ }^{* *}, \mathrm{~mm}$ & & 34.840 & 34.620 & -0.220 \\
\hline & & & \multicolumn{2}{|c|}{ Height, $\mathrm{mm}$} & 88.900 & 88.900 & 0.000 \\
\hline & & & \multicolumn{2}{|c|}{ Mass, grams } & 195.500 & 195.500 & 0.000 \\
\hline
\end{tabular}

$\mathrm{D}_{\mathrm{pl.}}{ }^{*}$ - distance between the planes;

$\mathrm{D}_{\text {ed. }}{ }^{* *}$ - distance between the edges. 


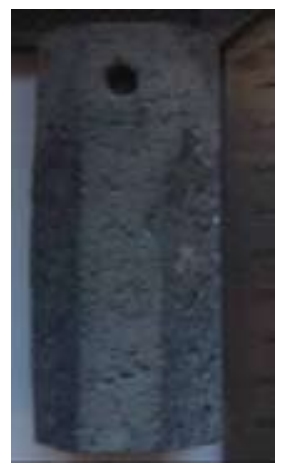

a

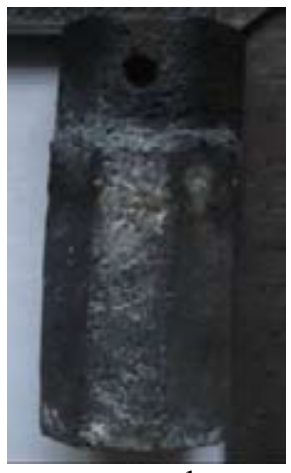

b

Fig. 8. Sample 1, silicon carbide: $\mathrm{a}$ - before the test; $\mathrm{b}$ - after the test

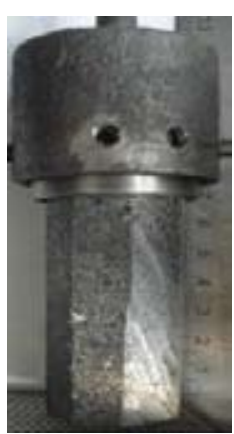

a

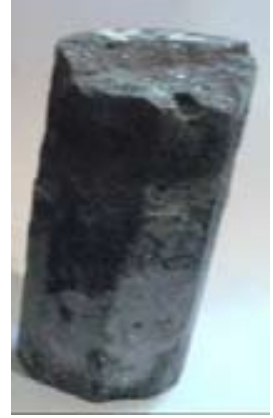

b

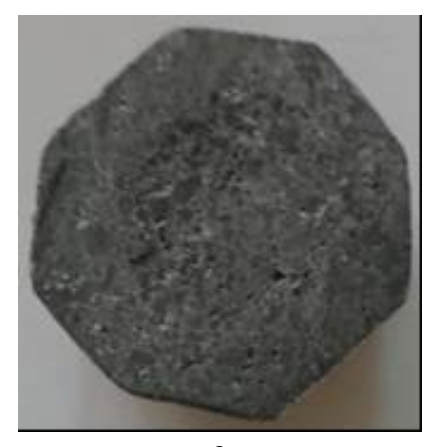

$\mathrm{c}$

Fig. 9. Sample 2, silicon carbide: $\mathrm{a}$ - before the test; $\mathrm{b}$ - after the test; $\mathrm{c}$ - cross-section when cut at the bath/ aluminum interface

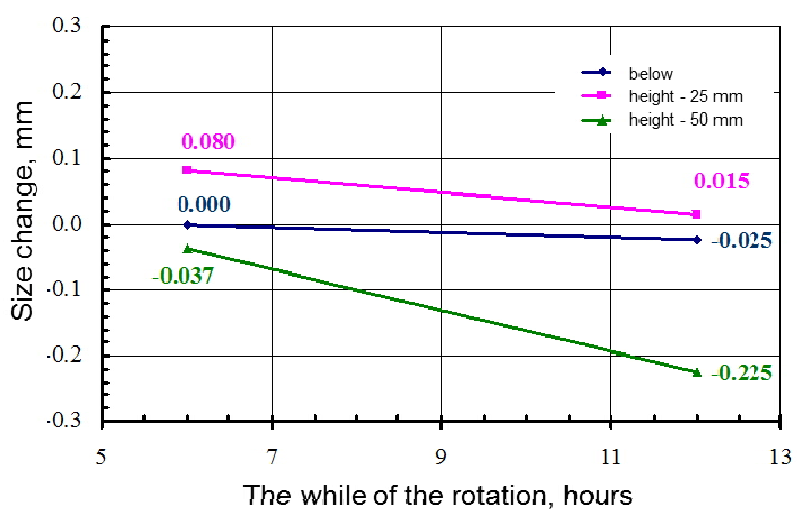

Fig. 10. Change in the distance between the faces of the silicon carbide samples vs. spinning time 
of 15 and $35 \mathrm{~mm}$. Fig. 13, 14 demonstrate cross-sections of the sample in three areas: a) aluminum area; b) bath area; and c) area above the bath.

As seen in the above Figures, the sample was impregnated the most within the bath area. The test results are listed in Table 4.

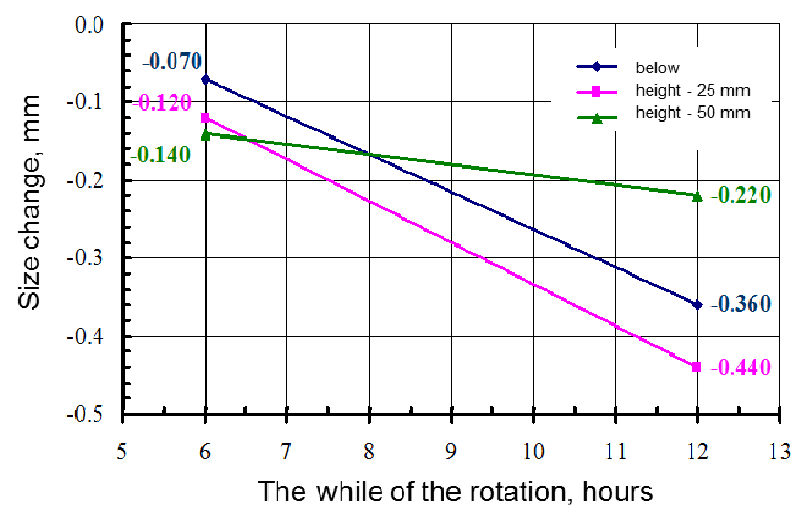

Fig. 11. Change in the distance between the edges of the silicon carbide samples vs. spinning time

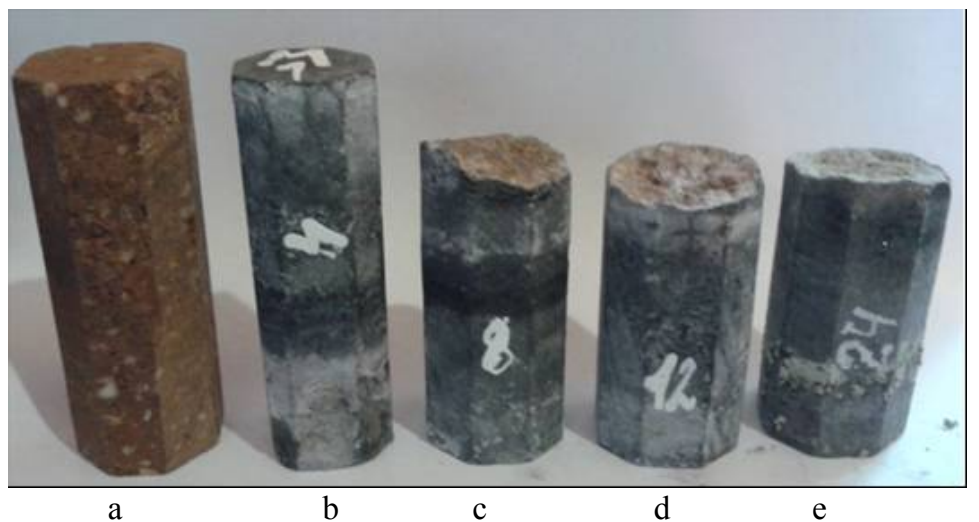

Fig. 12. The appearance of magnesite samples: $\mathrm{a}$ - before the test; $\mathrm{b}$ - after 4 hours; $\mathrm{c}-$ after 8 hours; $\mathrm{d}-$ after 12 hours; e - after 24 hours of spinning in the bath and aluminum

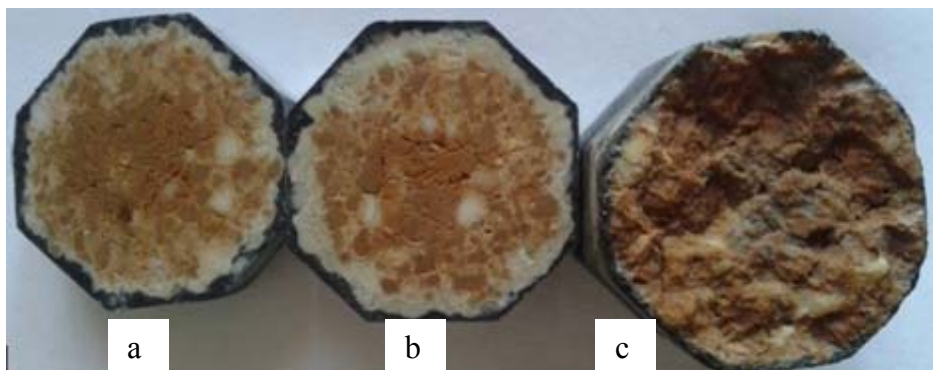

Fig. 13. Sample cross-section after 12 hours of spinning in the bath and aluminum: $a$ - aluminum area; $b$ - bath area; $\mathrm{c}$ - area above the bath 


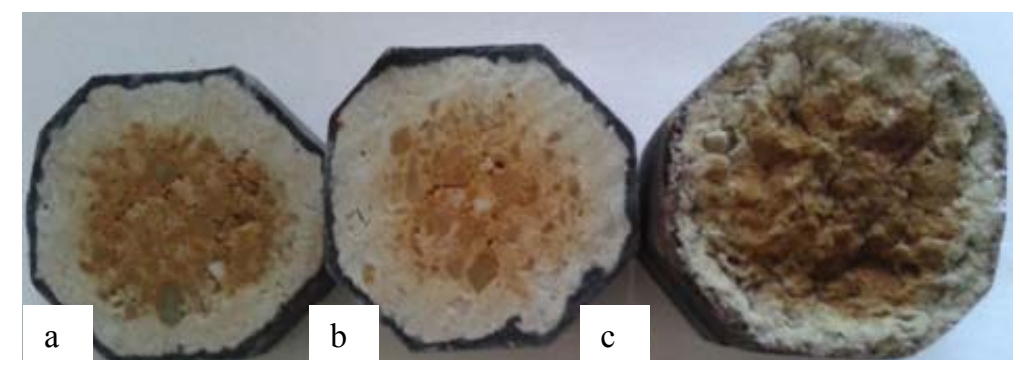

Fig. 14. Sample cross-section after 24 hours of spinning in the bath and aluminum: a - aluminum area; $b$ - bath area; $\mathrm{c}$ - area above the bath

Table 4. Test results: measuring the spinning wear of magnesite blocks in the bath-aluminum system

\begin{tabular}{|c|c|c|c|c|c|c|c|}
\hline $\begin{array}{l}\text { Test } \\
\text { No. }\end{array}$ & $\begin{array}{c}\text { Testing } \\
\text { time, hours }\end{array}$ & $\begin{array}{l}\text { Sample spinning } \\
\text { speed, } \mathrm{cm} / \mathrm{s}\end{array}$ & \multicolumn{2}{|c|}{$\begin{array}{c}\text { Average sample } \\
\text { dimensions and mass }\end{array}$} & Before test & After test & Difference \\
\hline 1 & 2 & 3 & 4 & 5 & 6 & 7 & 8 \\
\hline \multirow{8}{*}{1} & \multirow{8}{*}{4} & \multirow{8}{*}{16} & $\mathrm{D}_{\mathrm{pl} .}{ }^{*}, \mathrm{~mm}$ & \multirow{2}{*}{ at the bottom } & 27.375 & 27.750 & 0.375 \\
\hline & & & $\mathrm{D}_{\text {ed. }}{ }^{* *}, \mathrm{~mm}$ & & 29.320 & 29.260 & -0.060 \\
\hline & & & $\mathrm{D}_{\mathrm{pl} .}{ }^{*}, \mathrm{~mm}$ & \multirow{2}{*}{$\begin{array}{l}\text { at the height of } \\
25 \mathrm{~mm}\end{array}$} & 27.800 & 27.700 & -0.100 \\
\hline & & & $\mathrm{D}_{\text {ed. }}{ }^{* *}, \mathrm{~mm}$ & & 29.500 & 29.500 & 0.000 \\
\hline & & & $\mathrm{D}_{\mathrm{pl} .}{ }^{*}, \mathrm{~mm}$ & \multirow{2}{*}{$\begin{array}{c}\text { at the height of } \\
50 \mathrm{~mm}\end{array}$} & 27.700 & 27.875 & 0.175 \\
\hline & & & $\mathrm{D}_{\text {ed. }}{ }^{* *}, \mathrm{~mm}$ & & 29.480 & 29.320 & -0.160 \\
\hline & & & \multicolumn{2}{|c|}{ Height, mm } & & 89.900 & 0.000 \\
\hline & & & \multicolumn{2}{|c|}{ Mass, grams } & & 178.800 & 18.800 \\
\hline \multirow{8}{*}{2} & \multirow{8}{*}{8} & \multirow{8}{*}{16} & $\mathrm{D}_{\mathrm{pl} .}{ }^{*}, \mathrm{~mm}$ & \multirow{2}{*}{ at the bottom } & 32.875 & 33.400 & 0.525 \\
\hline & & & $\mathrm{D}_{\text {ed. }}{ }^{* *}, \mathrm{~mm}$ & & 35.340 & 35.440 & 0.100 \\
\hline & & & $\mathrm{D}_{\mathrm{pl} .}{ }^{*}, \mathrm{~mm}$ & \multirow{2}{*}{$\begin{array}{l}\text { at the height of } \\
25 \mathrm{~mm}\end{array}$} & 32.900 & 33.025 & 0.125 \\
\hline & & & $\mathrm{D}_{\text {ed. }}{ }^{* *}, \mathrm{~mm}$ & & 35.280 & 35.340 & 0.060 \\
\hline & & & $\mathrm{D}_{\mathrm{pl} .}{ }^{*}, \mathrm{~mm}$ & \multirow{2}{*}{$\begin{array}{l}\text { at the height of } \\
50 \mathrm{~mm}\end{array}$} & 32.875 & 33.400 & 0.525 \\
\hline & & & $\mathrm{D}_{\text {ed. }}{ }^{* *}, \mathrm{~mm}$ & & 35.220 & 35.140 & -0.080 \\
\hline & & & \multicolumn{2}{|c|}{ Height, $\mathrm{mm}$} & & 89.750 & 0.000 \\
\hline & & & \multicolumn{2}{|c|}{ Mass, grams } & & 253.000 & 25.900 \\
\hline \multirow{8}{*}{3} & \multirow{8}{*}{12} & \multirow{8}{*}{9} & $\mathrm{D}_{\mathrm{pl} .}{ }^{*}, \mathrm{~mm}$ & \multirow{2}{*}{ at the bottom } & 33.300 & 33.525 & 0.225 \\
\hline & & & $\mathrm{D}_{\text {ed. }}{ }^{* *}, \mathrm{~mm}$ & & 35.560 & 35.740 & 0.180 \\
\hline & & & $\mathrm{D}_{\mathrm{pl} .}{ }^{*}, \mathrm{~mm}$ & \multirow{2}{*}{$\begin{array}{l}\text { at the height of } \\
25 \mathrm{~mm}\end{array}$} & 33.300 & 33.575 & 0.275 \\
\hline & & & $\mathrm{D}_{\text {ed. }}{ }^{* *}, \mathrm{~mm}$ & & 35.580 & 35.900 & 0.320 \\
\hline & & & $\mathrm{D}_{\mathrm{pl} .}{ }^{*}, \mathrm{~mm}$ & \multirow{2}{*}{$\begin{array}{l}\text { at the height of } \\
50 \mathrm{~mm}\end{array}$} & 33.250 & 33.400 & 0.150 \\
\hline & & & $\mathrm{D}_{\text {ed. }}{ }^{* *}, \mathrm{~mm}$ & & 34.660 & 35.280 & 0.620 \\
\hline & & & \multicolumn{2}{|c|}{ Height, mm } & & 89.340 & 0.000 \\
\hline & & & \multicolumn{2}{|c|}{ Mass, grams } & & 255.900 & 24800 \\
\hline \multirow{4}{*}{4} & \multirow{4}{*}{24} & \multirow{4}{*}{9} & $\mathrm{D}_{\mathrm{pl} .}{ }^{*}, \mathrm{~mm}$ & \multirow{2}{*}{ at the bottom } & 33.350 & 33.275 & -0.075 \\
\hline & & & $\mathrm{D}_{\text {ed. }}{ }^{* *}, \mathrm{~mm}$ & & 35.900 & 36.000 & 0.100 \\
\hline & & & $\mathrm{D}_{\mathrm{pl} .}{ }^{*}, \mathrm{~mm}$ & \multirow{2}{*}{$\begin{array}{l}\text { at the height of } \\
25 \mathrm{~mm}\end{array}$} & 33.300 & 33.375 & 0.075 \\
\hline & & & $\mathrm{D}_{\text {ed. }}{ }^{* *}, \mathrm{~mm}$ & & 35.440 & 35.600 & 0.160 \\
\hline
\end{tabular}


Table 4. Continued

\begin{tabular}{|c|c|c|c|c|c|c|c|}
\hline 1 & 2 & 3 & 4 & 5 & 6 & 7 & 8 \\
\hline & & & $\mathrm{D}_{\mathrm{pl} .}{ }^{*}, \mathrm{~mm}$ & \multirow{2}{*}{$\begin{array}{l}\text { at the height of } \\
50 \mathrm{~mm}\end{array}$} & 33.375 & 33.55 & 0.175 \\
\hline & & & $\mathrm{D}_{\text {ed. }}{ }^{* *}, \mathrm{~mm}$ & & 35.520 & 35.460 & -0.060 \\
\hline & & & \multicolumn{2}{|c|}{ Height, mm } & & 89.400 & 0.000 \\
\hline & & & \multicolumn{2}{|c|}{ Mass, grams } & & 260.100 & 31.100 \\
\hline
\end{tabular}

$\mathrm{D}_{\mathrm{pl} .}{ }^{*}$ - distance between the planes;

$\mathrm{D}_{\text {ed. }}{ }^{* *}-$ distance between the edges.

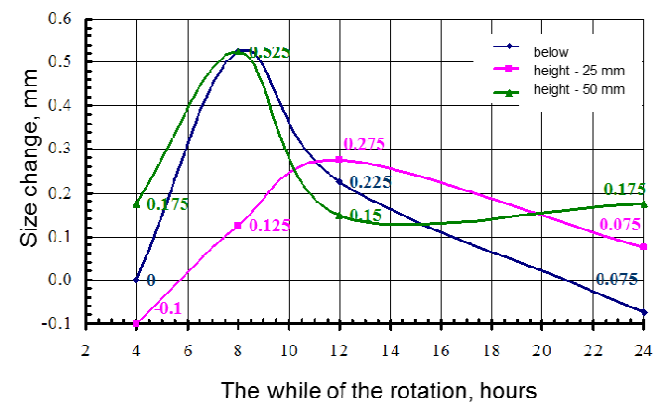

Fig. 15. Change in the distance between the faces of the magnesite samples vs. spinning time

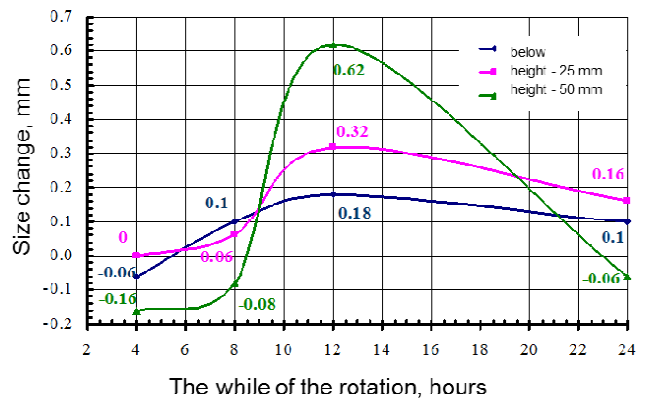

Fig. 16. Change in the distance between the edges of the magnesite samples vs. spinning time

It is shown that all the samples became heavier after the tests, which makes it impossible to define the extent of spinning wear of these blocks in the bath-aluminum system.

Figures 15 and 16 show the change in the sample dimensions as a function of time and height.

The graphs and pictures demonstrate that the samples were impregnated to a great extent and became bigger. The change in the dimensions was less significant at the later stage of the test, so the PShGS-64 (ПШГС-64) samples were supposedly subject to wear, but it was difficult to define the degree of wear.

The tests showed that neither of the materials was destroyed by the bath and aluminum after 24 hours of testing, so both of them can be used for forming artificial ledges, because the walls of the cell are usually fully protected by a layer of molten aluminum in $18-26$ hours after the start-up. 


\section{Coefficient of Thermal Expansion (CTE) for magnesite blocks}

The rated CTE of silicon carbide blocks is $4.6 \cdot 10^{-6} \mathrm{~K}^{-1}$ (according to the quality certificate). The CTE of magnesite blocks was not defined by the manufacturer, so it was necessary to measure it. The IK-4 (ИК-4) measurement system was used. The experiment was run according to the methods of СТЕ experimental measurement in the temperature range of 20 to $950{ }^{\circ} \mathrm{C}$.

The graph in Fig. 17 shows the results of the measurement within the temperature range of 20 to $950{ }^{\circ} \mathrm{C}$. The vertical axis represents the relative change in the height of the sample defined as:

$$
\varepsilon=\Delta \mathrm{h} / \mathrm{h}_{0} \cdot 100 \%,
$$

where $\varepsilon$ stands for the relative change measured in $\% ; \Delta \mathrm{h}$ stands for the absolute change measured in $\mathrm{mm} ; \mathrm{h}_{0}$ stands for the initial height of the sample measured in $\mathrm{mm}$.

The Coefficient of Thermal Expansion (CTE) was counted as:

$$
\alpha=\varepsilon / \Delta \mathrm{T}
$$

where $\alpha$ stands for the CTE measured in ${ }^{\circ} \mathrm{K}^{-1}$; stands for the relative change in the height of the sample heated from the room temperature $\mathrm{T}_{0}$ to $\mathrm{T}=(950 \pm 10)^{\circ} \mathrm{C} ; \Delta \mathrm{T}$ stands for the change in temperature from the room temperature $\mathrm{T}_{0}$ to $\mathrm{T}=(950 \pm 10){ }^{\circ} \mathrm{C}$.

The measurement results for PShGS-64 (ПШГС-64) are listed in the Table 5.

The experiments showed that the magnesite block's CTE ranged within $11.1 \cdot 10^{-6}$ to $11.2 \cdot 10^{-6}$ in the temperature range of 20 to $950^{\circ} \mathrm{C}$. This means that magnesite is a suitable material for artificial ledges, since the internal stress will not break it when the temperature rises.

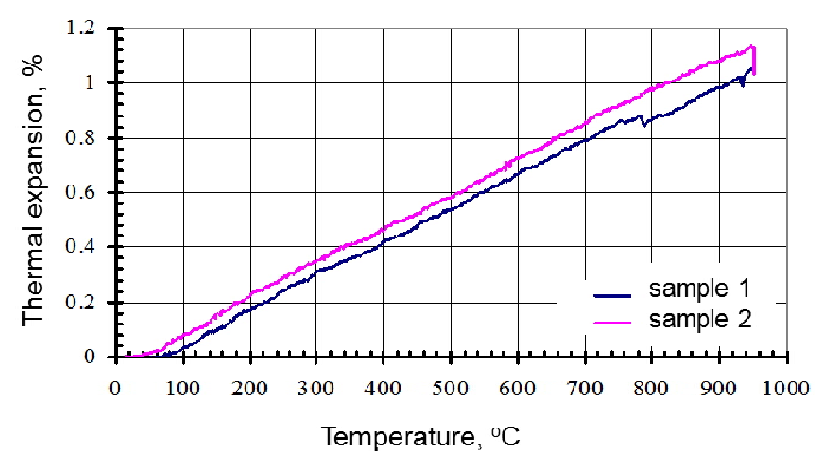

Fig. 17. Thermal expansion of the PShGS-64 (ПШГС-64) block vs. temperature

Table 5. Characteristics of the PShGS-64 (ПШГС-64) magnesite samples before and after the experiment

\begin{tabular}{|c|l|c|c|c|c|c|}
\hline \multicolumn{2}{|c|}{ Experiment No. } & $\mathrm{m}, \mathrm{g}$ & $\mathrm{d}, \mathrm{mm}$ & $\mathrm{h}, \mathrm{mm}$ & Density, grams $/ \mathrm{cm}^{3}$ & \multirow{2}{*}{$\mathrm{CTE}^{\circ}{ }^{\mathrm{K}}{ }^{-1}$} \\
\hline \multirow{2}{*}{1} & Before the experiment & 205.40 & 42.92 & 50.67 & 2.80 & \multirow{2}{*}{$11.2 \cdot 10^{-6}$} \\
\cline { 2 - 7 } & After the experiment & 205.00 & 41.65 & 50.89 & 2.96 & \\
\hline \multirow{2}{*}{2} & Before the experiment & 204.10 & 41.51 & 50.47 & 2.99 & \multirow{2}{*}{$11.1 \cdot 10^{-6}$} \\
\cline { 2 - 6 } & After the experiment & 203.60 & 42.00 & 50.78 & 2.89 & \\
\hline
\end{tabular}




\section{Thermal conductivity (TC)}

of silicon carbide and magnesite blocks

The rated $\mathrm{TC}$ of silicon carbide blocks is $28 \mathrm{~W} / \mathrm{m} \cdot \mathrm{K}\left(\mathrm{T}=300{ }^{\circ} \mathrm{C}\right)$ and $20 \mathrm{~W} / \mathrm{m} \cdot \mathrm{K}\left(\mathrm{T}=950{ }^{\circ} \mathrm{C}\right)$ (according to the quality certificate). The TC of magnesite blocks was not defined by the manufacturer, so it was necessary to measure it. The ТЕР (ТЭП) measurement system was used. The experiment was run according to the methods of thermal conductivity experimental measurement within the temperature range of 100 to $950{ }^{\circ} \mathrm{C}$.

The results of the measurement within the temperature range of 100 to $950{ }^{\circ} \mathrm{C}$ are shown in Fig. 18 as TC/temperature dependency graphs. The measured TC values at different temperature levels for magnesite blocks are listed in Table 6 .

These results can be used for mathematical modeling when estimating the thermal balance of the cell.

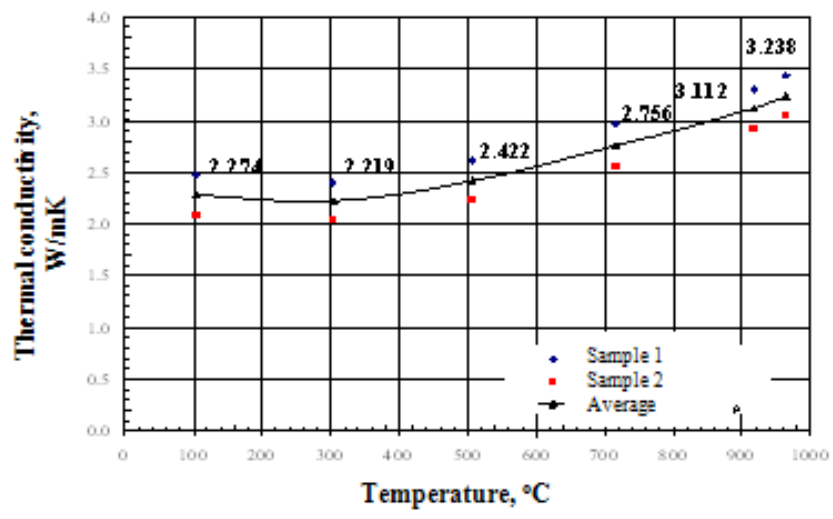

Fig. 18. Thermal conductivity of the PShGS-64 (ПШГС-64) magnesite block

Table 6. Thermal conductivity of the PShGS-64 (ПШГС-64) magnesite block

\begin{tabular}{|c|c|c|c|c|}
\hline $\begin{array}{c}\text { Experiment } \\
\text { No. }\end{array}$ & $\begin{array}{c}\text { Temperature, } \\
{ }^{\circ} \mathrm{C}\end{array}$ & $\mathrm{TC}, \mathrm{W} / \mathrm{m} \cdot \mathrm{K}$ & $\begin{array}{c}\text { Apparent density before } \\
\text { the experiment, } \mathrm{g} / \mathrm{cm}^{3}\end{array}$ & $\begin{array}{c}\text { Apparent density after } \\
\text { the experiment, } \mathrm{g} / \mathrm{cm}^{3}\end{array}$ \\
\hline \multirow{5}{*}{1} & 103.28 & 2.469 & & \\
\cline { 2 - 3 } & 303.84 & 2.397 & & \multirow{2}{*}{2.78} \\
\cline { 2 - 3 } & 506.25 & 2.616 & \multirow{2}{*}{2.79} & \\
\cline { 2 - 3 } & 716.32 & 2.963 & & \\
\cline { 2 - 3 } & 918.71 & 3.303 & & \\
\cline { 2 - 3 } & 963.41 & 3.437 & & \\
\hline \multirow{5}{*}{2} & 103.28 & 2.078 & & \\
\cline { 2 - 3 } & 303.84 & 2.041 & & \\
\cline { 2 - 3 } & 506.25 & 2.229 & & \\
\cline { 2 - 3 } & 716.32 & 2.548 & & \\
\cline { 2 - 3 } & 918.71 & 2.920 & & \\
\cline { 2 - 3 } & 963.41 & 3.040 & & \\
\end{tabular}


Properties of silicon carbide and magnesite blocks

for mathematical modelling

Apparent density $\rho, \mathrm{g} / \mathrm{cm}^{3}$

- PShGS-64 magnesite block (experimental value) $\quad-2.79$

- Silicon carbide block (rated value) $\quad-2.58$

Coefficient of Thermal Expansion $\alpha,{ }^{\circ} \mathrm{K}^{-1}$

- PShGS-64 magnesite block (experimental value) $\quad-11.2 \cdot 10^{-6}$

- Silicon carbide block (rated value) $\quad-4.6 \cdot 10^{-6}$

Thermal conductivity $\lambda, \mathrm{W} / \mathrm{m} \cdot \mathrm{K}$

- PShGS-64 magnesite block (experimental value

$\begin{array}{llllllll}\mathrm{T},{ }^{\circ} \mathrm{C} & 100 & 300 & 500 & 700 & 800 & 900 & 950\end{array}$

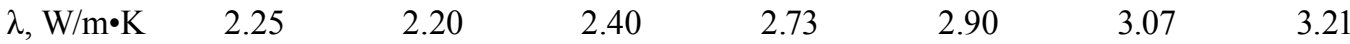

- Silicon carbide block (rated value)

$\mathrm{T},{ }^{\circ} \mathrm{C} \quad 300 \quad 950$

$\lambda, \mathrm{W} / \mathrm{m} \cdot \mathrm{K} \quad 28 \quad 20$

The tests showed that neither of the materials was destroyed when exposed to the circulating bath melt for 24 hours. Neither material was subject to wear when exposed to the circulating aluminum melt. Thus, both materials can be used for artificial ledges, because the walls of the cell are usually fully protected by a layer of molten aluminum in $18-26$ hours after the startup.

Experiments showed that the magnesite block's CTE ranged within $11,1 \cdot 10^{-6}$ to $11,2 \cdot 10^{-6}$ in the temperature range of 20 to $950{ }^{\circ} \mathrm{C}$. This means that magnesite is a suitable material for artificial cell ledge formation, since the internal stress will not break it when the temperature rises.

\section{Conclusions}

The following goals were achieved by this research:

- the thermal conductivity of silicon carbide and magnesite blocks was investigated;

- temperature vs. electrical resistivity of silicon carbide and magnesite blocks was analyzed;

- the thermal expansion coefficient for magnesite blocks was defined;

- the properties of silicon carbide and magnesite blocks were investigated for mathematical modelling purposes;

- wear-resistance tests of the materials were conducted.

As a result of the research, two materials were chosen for artificial ledge formation:

a) $\mathrm{SiC}-\mathrm{SiN}$ based material; and

b) magnesite based material.

Both materials demonstrated high resistivity against the bath melt and can be recommended for artificial ledge formation.

\section{References}

[1] Appendix 1 to the production certificate for silicon carbide blocks.

[2] Production certificate № 32010575 от 07.10.2014 for magnesite blocks. 
[3] Chunxia Liu, Zhigang Huang, Guohua Liu, Zhiping Zhang. Excellent Cryolite Resistence and High Thermal Conductivity SiC Sidewall Material For High Amperage Aluminium Reduction Cells, Light Metals, 2010, 889-894.

[4] George E., Marguni O., Temme P. Use of nitride-bonded silicon carbide bricks as a refractory material for aluminum cells, Siberian Aluminum: collection of scientific articles. Bona Company. Krasnoyarsk, 2003, 203-208.

[5] Wang Zh., Skybakmoen E., Grande T. Spent $\mathrm{Si}_{3} \mathrm{~N}_{4}$ Bonded SiC Sidelining Materials in Aluminium Electrolysis Cells, LightMetals, 2009, 353-358.

[6] Чиркин В.С. Теплофизические свойства материалов ядерной техники. М.: Атомиздат, 1967, 474 c. [Chirkin V.S. Thermophysical properties of nuclear engineering materials. Moscow, Atomizdat, 1967, 474 p. (in Russian)]

[7] Казанцев Е.И. Промышленные печи. Справочное руководство для расчетов и проектирования, 2-е изд., доп. и перераб. М.: Металлургия, 1975, 368 с. [Kazantsev E.I. Industrial furnace. Reference guide for calculations and design, Moscow, Metalurgiia, 1975, 368 p. (in Russian)] 